\title{
Transcriptome profiling of lactococcal mixed culture activity in milk by fluorescent RNA arbitrarily primed-PCR
}

\author{
Fabien DACHET ${ }^{1}$, Daniel St-GelaIS ${ }^{2}$, Denis Roy ${ }^{1}$, Gisèle LAPoINTE ${ }^{1 *}$ \\ ${ }^{1}$ Institute for Nutraceuticals and Functional Foods, STELA Dairy Research Centre, Université Laval, \\ Québec, QC, G1V 0A6, Canada \\ ${ }^{2}$ Agriculture et Agroalimentaire Canada, CRDA, Saint-Hyacinthe, QC, J2S 8E3, Canada
}

Received 18 July 2009 - Revised 4 January 2010 - Accepted 28 January 2010

Published online 30 March 2010

\begin{abstract}
Thermal treatment of milk is widely used to reduce milk contamination, while $\mathrm{CO}_{2}$ can be used to prevent bacterial growth and maintain milk quality during storage. These treatments applied before or during cheese manufacture could alter the metabolic activity of starter cultures. Changes in gene expression can be evaluated by differential display methods, so that effects on bacterial metabolic activity can be estimated by variation in transcription profiles. The aim of this study was to develop fluorescent RNA arbitrarily primed-polymerase chain reaction (RAP-PCR) as a method to evaluate the influence of milk $\mathrm{CO}_{2}$ acidification as well as rennet and salt concentrations on starter gene expression. Comparison with reference conditions showed that gene transcription was influenced according to the extent of thermal treatment as well as by $\mathrm{CO}_{2}$ acidification followed by different neutralization procedures. Thus, simple acid neutralization after $\mathrm{CO}_{2}$ acidification was not sufficient to regain the reference transcriptome profile. Starter gene transcription profiles showed important modifications following an increase in $\mathrm{NaCl}$ concentration or a decrease in rennet activity from standard conditions used in Cheddar cheese making. Increasing rennet activity results in small changes in the starter RNA profile. Fluorescent RAP-PCR is a promising method for obtaining a better understanding of gene expression profiles of mixed cultures during cheese making.
\end{abstract}

Lactococcus / starter culture / dairy product / carbon dioxide / RAP-PCR / transcription profile

摘要 - 荧光 RNA 随机引物 PCR 方法检测乳中乳球菌混合培养物转录谱。热处理广泛地用于 降低乳的污染，而在败藏过程中 $\mathrm{CO}_{2}$ 能防止细菌生长并维持乳的品质。干酪加工过程 中或者加工前的这些处理, 能够改变发酵剂的代谢活动。基因表达的变化可以通过不同 的显示方法来评价, 因此可以通过转录谱的变化来评价不同因素对细菌代谢活动的 影响。本研究旨在建立苂光 RNA 随机引物 PCR (RAP-PCR) 方法来评价乳 $\mathrm{CO}_{2}$ 酸化、皱 胃酶浓度、盐浓度对发酵剂基因表达的影响。与参照条件相比, 热处理、伴随着不同中和 处理过程的 $\mathrm{CO}_{2}$ 的酸化均使发酵剂基因转录水平受到了影响。因此 $\mathrm{CO}_{2}$ 酸化后, 简单酸 中和不能充分地恢复基本的转录水平。在 Cheddar 干酪制作过程中的标准条件的基础上, 随 着 $\mathrm{NaCl}$ 浓度的增加, 或者皱胃酶活性的降低, 发酵剂的基因转录出现了重要的改变。皱胃 酶活性的增加导致了发酵剂 RNA 谱发生小的变化。苂光 RAP-PCR 为更好地理解干酪制作过 程中混合发酵剂的基因表达谱的变化，提供了好的方法。

\section{Lactococcus / 发酵剂 / 乳制品 / $\mathrm{CO}_{2} / \mathrm{RAP}-\mathrm{PCR} /$ 转录谱}

*Corresponding author (通讯作者): gisele.lapointe@fsaa.ulaval.ca 
Résumé - Analyse du profil transcriptomique d'une culture mixte de lactocoques dans le lait par RAP-PCR fluorescente. Pour réduire la contamination microbienne du lait, un traitement thermique est généralement appliqué et une dissolution de $\mathrm{CO}_{2}$ peut être utilisée pour ralentir la prolifération des bactéries et augmenter la durée de conservation du lait. Ces traitements appliqués avant ou pendant la fabrication fromagère peuvent modifier l'activité métabolique du ferment. Les méthodes d'affichage différentiel révèlent les changements dans l'expression des gènes, donc les effets sur l'activité métabolique peuvent être estimés par la variation des profils de transcription. Cette étude avait pour but de développer la méthode RAP-PCR fluorescente pour évaluer l'influence de trois facteurs sur l'expression des gènes du ferment : l'acidification du lait par le $\mathrm{CO}_{2}$, la concentration en présure et la concentration en sel. La comparaison des profils de transcription avec un ferment cultivé en conditions de référence a montré que l'expression des gènes était influencée par un traitement thermique excessif et par une acidification par ajout de $\mathrm{CO}_{2}$ suivie d'une étape de neutralisation. Ainsi, une simple neutralisation de l'acide présent après l'acidification d'un lait par l'ajout de $\mathrm{CO}_{2}$ n'était pas suffisante pour rétablir le profil de transcription identique au profil de référence. Par comparaison aux conditions de références rencontrées lors de la fabrication d'un fromage de type Cheddar, le profil de transcription du ferment apparaissait principalement influencé par une forte concentration de $\mathrm{NaCl}$ et une faible activité de la présure. Une forte activité de la présure n'avait qu'un faible effet sur le profil des ARN du ferment. La RAP-PCR fluorescente est une technique prometteuse pour obtenir une meilleure compréhension de la transcription globale des gènes de cultures mixtes durant une fermentation fromagère.

\section{Lactococcus / ferment / produit laitier / dioxyde de carbone / RAP-PCR / transcriptome}

\section{INTRODUCTION}

During Cheddar cheese making, starter cultures produce enzymes responsible for acidification, proteolysis and metabolite production. These enzymes will influence the organoleptic characteristics of the fermented product. Numerous parameters determine the stability and success of fermentations by affecting the metabolic activity of the microorganisms, including, for example, milk contaminants such as antibiotics and bacteriophages. Thermal or $\mathrm{CO}_{2}$ treatment of milk, minerals and rennet could affect milk components and thus modify bacterial metabolic activity resulting in a potential fermentation deviation leading to variations in cheese quality.

Monitoring the metabolic activity of strains and starters is most commonly done by $\mathrm{pH}$ measurement and lactic acid determination during fermentation. Individual biochemical tests do not describe the entire enzymatic activity of starters, where from 1000 to 2800 different proteins can be synthesized during fermentation [13]. Thus, variation in $\mathrm{pH}$ kinetics does not reveal deviations in other enzymatic activities that could affect cheese quality, which is usually determined by sensory evaluation and analytical tests after the costly ripening process. Each enzyme results from mRNA translation, so metabolic activity should be correlated with gene expression by the culture. Our hypothesis is that milk treatments which alter starter activity during fermentation could be detected by comparison of RNA profiles. Microarrays [26], which analyze whole transcriptomes, can be applied when the genome is known. However, if the genome has not been sequenced, the techniques of differential display $[30,31]$ can be applied to evaluate modifications in transcriptomes according to various conditions either in eucaryotes [10, 29] or in procaryotes [32]. The two molecular techniques of cDNA amplified fragment length polymorphism (cDNA-AFLP) [1] and RNA arbitrarily primed-polymerase chain reaction (RAP-PCR) [32] are the most frequently used for evaluating modifications in transcriptomes [15]. However, cDNA-AFLP requires restriction sites so 
Table I. $\mathrm{pH}$ of thermal treated milk during fermentation using defined mixed starter culture at the $\mathrm{T} 1$ and $\mathrm{T} 2$ time points of the modified Pearce test.

\begin{tabular}{llll}
\hline Abbreviation & \multicolumn{1}{c}{ Milk types and thermal treatment } & \multicolumn{2}{c}{$\mathrm{pH} \pm \mathrm{SD}^{*}$} \\
\cline { 3 - 4 } & & \multicolumn{1}{c}{$\mathrm{T} 1$} & $\mathrm{~T} 2$ \\
\hline SMPA10 & Skim milk powder autoclaved $10 \mathrm{~min}$ at $120^{\circ} \mathrm{C}$ & $5.31 \pm 0.07$ & $4.81 \pm 0.08$ \\
SMPA15 & Skim milk powder autoclaved $15 \mathrm{~min}$ at $120^{\circ} \mathrm{C}$ & $5.08 \pm 0.05^{* *}$ & $4.78 \pm 0.04$ \\
SMPP & Skim milk powder pasteurized $30 \mathrm{~min}$ at $65{ }^{\circ} \mathrm{C}$ & $5.16 \pm 0.07$ & $4.74 \pm 0.07$ \\
UHT & Commercial milk treated 2 $\mathrm{s}$ at $140{ }^{\circ} \mathrm{C}$ & $5.46 \pm 0.16$ & $4.73 \pm 0.06$ \\
MF & Commercial microfiltered milk & $5.40 \pm 0.11$ & $4.70 \pm 0.09$ \\
\hline
\end{tabular}

${ }^{*}$ SD is standard deviation.

** $P<0.05$ within each time point.

transcripts without correct sites will not be revealed at all, while RAP-PCR uses acrylamide electrophoresis that lacks the resolution necessary to efficiently separate amplimers [2]. Fluorescent RAP-PCR or FRAP-PCR [4] uses fluorescent primers and an automated capillary sequencer instead of acrylamide electrophoresis. The differentially expressed amplimers are not identified directly $[11,27]$, but they can be separated without ambiguity and increase the throughput of differential display analysis [8], while allowing statistical comparison of profiles. The aim of this study was to investigate the effect of $\mathrm{CO}_{2}$ acidification of milk, $\mathrm{NaCl}$ and rennet on global starter activity by comparing transcriptome profiles obtained by FRAP-PCR. Reference conditions for standardizing the comparison of transcriptome profiles were determined by studying the influence of milk preparation (whole milk versus skim milk powder, SMP) and thermal treatment (UHT, microfiltration, pasteurization and autoclaving).

\section{MATERIALS AND METHODS}

\subsection{Strains and culture conditions}

The defined mixed starter culture consisted of three Lactococcus lactis subsp. cremoris strains in equal proportions: LL074, LL225 and LL390 (DSM Food
Specialities, Inc., NJ, USA). Two successive cultures inoculated at $1 \%$ were incubated at $22{ }^{\circ} \mathrm{C}$ in UHT milk, the first for $18 \mathrm{~h}$ and the second for $16 \mathrm{~h}$. The final culture was inoculated at $3 \%$ in each type of milk to be analyzed (Tab. I) at the T0 time point of the Pearce test (Supplementary Material, Fig. S1, available at www.dairy-journal. org). The incubation parameters of the Pearce test simulate the characteristic temperature and time profile of Cheddar cheese making [19]. Fermentations were done in triplicate and $\mathrm{pH}$ was recorded. When required, $\mathrm{CaCl}_{2}$ at the final concentration of $0.2 \mathrm{~g} \cdot \mathrm{L}^{-1}$ and rennet were added at T0. Rennet (Chymax, Fromagex, Rimouski, QC, Canada) was applied at low, standard or high concentrations: $0.04,0.08$ or $0.12 \mathrm{~g} \cdot \mathrm{L}^{-1}$, respectively. $\mathrm{NaCl}$ was added at the $\mathrm{T} 4$ time point at one of the three concentrations: $15 \mathrm{~g} \cdot \mathrm{L}^{-1}$ (low), $22.5 \mathrm{~g} \cdot \mathrm{L}^{-1}$ (standard) or $25 \mathrm{~g} \cdot \mathrm{L}^{-1}$ (high). For each concentration of rennet tested, only the standard $\mathrm{NaCl}$ concentration was used and for each $\mathrm{NaCl}$ concentration tested, the standard rennet concentration was applied.

\subsection{Preparation of acidified milk and neutralization}

Skim milk was commercially pasteurized milk with $0.1 \%$ MF (milk fat). Raw whole milk was obtained from Agropur (Natrel division, QC, Canada) prior to homogenization and then pasteurized at $65^{\circ} \mathrm{C}$ for 
Table II. Summary of milk acidification and neutralization steps and $\mathrm{pH}$ of acidified and neutralized pasteurized whole and skim milk at the T4 time point during the Pearce test.

\begin{tabular}{llllc}
\hline Abbreviation & \multicolumn{1}{c}{ Milk type } & $\begin{array}{c}\text { Acidification } \\
(\mathrm{pH} \mathrm{6.2)}\end{array}$ & \multicolumn{1}{c}{$\begin{array}{c}\text { Neutralization } \\
(\mathrm{pH} \mathrm{6.7})\end{array}$} & $\begin{array}{c}\mathrm{pH} \pm \mathrm{SD}^{*} \\
\text { at T4 time point }\end{array}$ \\
\hline WR & Whole milk reference & $\mathrm{None}$ & None & $4.77 \pm 0.06$ \\
WCN & Whole & $\mathrm{CO}_{2}$ & $\mathrm{NaOH}$ & $5.23 \pm 0.28^{* *}$ \\
WCC & Whole & $\mathrm{CO}_{2}$ & $\mathrm{Na}_{2} \mathrm{CO}_{3}$ & $6.21 \pm 0.34^{* *}$ \\
WCA & Whole & $\mathrm{CO}_{2}$ & $\mathrm{Stirring}$ at $4{ }^{\circ} \mathrm{C}$ & $4.79 \pm 0.04$ \\
WHN & Whole & $\mathrm{HCl}$ & $\mathrm{NaOH}$ & $4.71 \pm 0.10$ \\
SR & Skim milk reference & $\mathrm{None}$ & None & $5.35 \pm 0.34$ \\
SC & Skim & $\mathrm{CO}_{2}$ & None & $5.39 \pm 0.38$ \\
SCA & Skim & $\mathrm{CO}_{2}$ & Stirring at $4{ }^{\circ} \mathrm{C}$ & $5.16 \pm 0.40$ \\
\hline
\end{tabular}

${ }^{*} \mathrm{SD}$ is standard deviation.

${ }^{* *} P<0.05$ (comparing $\mathrm{pH}$ values of five pasteurized whole milk samples only).

30 min. The same day, separate pasteurized milk aliquots of $100 \mathrm{~mL}$ were mixed with filtered $\mathrm{CO}_{2}$ gas (pores: $0.2 \mu \mathrm{mol} \cdot \mathrm{L}^{-1}$ ) until $\mathrm{pH}$ 6.2. This acidification led to a $\mathrm{CO}_{2}$ concentration of around $30.0-38.6 \mathrm{mmol} \cdot \mathrm{L}^{-1}$ $[12,14]$. As a comparative control, milk acidification was also performed with $5 \mathrm{~mol} \cdot \mathrm{L}^{-1} \mathrm{HCl}$ until the $\mathrm{pH}$ attained 6.2 . As a $\mathrm{pH}$ of 6.7 is necessary in order to ensure high-quality cheese, acidified milk must be neutralized before cheese making. So in this study, acidified milk was neutralized in three ways until $\mathrm{pH}$ returned to the reference value of 6.7 , by adding $5 \mathrm{~mol} \cdot \mathrm{L}^{-1}$ of $\mathrm{NaOH}$ or $\mathrm{Na}_{2} \mathrm{CO}_{3}$ powder $(0.8 \pm 0.2 \mathrm{~g}$ for $100 \mathrm{~mL}$ of milk) or by degassing with agitation at $4{ }^{\circ} \mathrm{C}$ (Tab. II). After acidification and neutralization, each milk treatment was then inoculated at 3\% with defined mixed starter at the T0 time point of the Pearce test.

\subsection{Cell harvesting}

Seven-milliliter samples withdrawn at either T1 and T2, or T4 or T5 of the Pearce test were mixed in equal ratio with RNAProtect $^{\circledR}$ (Qiagen, Mississauga, ON, Canada). Centrifugation at $4500 \times g$ (no holding time) was first applied to separate the protein debris (casein micelles), while the liquid containing the bacteria was transferred to a new tube for a centrifugation at $16000 \times g$ (no holding time). Lipids (from milk fat) were rapidly removed from the tube top with a brush and the liquid phase discarded. The pellet was suspended in $2 \mathrm{~mL}$ of RNAProtect ${ }^{\circledR}$ in a $2-\mathrm{mL}$ screw-capped tube and incubated for $5 \mathrm{~min}$ at room temperature. After centrifugation at $20000 \times g$ (no holding time), the floating material was discarded by inversion, and the pellet was washed in the same tube with $1.5 \mathrm{~mL}$ of RNAProtect ${ }^{\circledR}$ followed by centrifugation at $20000 \times g$ (no holding time).

\subsection{Cell lysis and RNA purification}

After evacuating the RNAProtect ${ }^{\circledR}$, the cell pellet was suspended in $500 \mu \mathrm{L}$ of lysis buffer $\left(100 \mathrm{~g} \cdot \mathrm{L}^{-1}\right.$ lysozyme and $10 \%$ sucrose, $\mathrm{pH} 5$ ) and incubated for $5 \mathrm{~min}$ at $46^{\circ} \mathrm{C}$. A volume of $1 \mathrm{~mL}$ of Trizol $^{\circledR}$ (Invitrogen, Burlington, ON, Canada) at $46{ }^{\circ} \mathrm{C}, 200 \mu \mathrm{L}$ of chloroform and $100 \mu \mathrm{L}$ of $\beta$-SDS $(10 \%$ sodium dodecyl sulfate and $1 \% \quad \beta$-mercaptoethanol) were added successively and mixed. After incubation for $5 \mathrm{~min}$ at $46^{\circ} \mathrm{C}$, the phases were blended by agitation then separated by centrifugation in a precooled centrifuge $(20000 \times \mathrm{g}$ for 5 min at $4{ }^{\circ} \mathrm{C}$ ). 
One milliliter of the aqueous phase was mixed with $500 \mu \mathrm{L}$ of isopropanol at room temperature and then passaged twice on an RNeasy $^{\circledR}$ column (Qiagen, Mississauga, $\mathrm{ON}$, Canada) by centrifugation at $14000 \times g$ for $15 \mathrm{~s}$. The manufacturer's protocol was followed for washing and on-column DNase treatment, except that 33 units of SUPERaseIn $^{\mathrm{TM}}$ (Ambion, Applied Biosystems, Foster City, USA) were added. The RNA elution was carried out on ice with $10 \mu \mathrm{L}$ of RNase-free water. The RNA concentration was quantified at $260 \mathrm{~nm}$ with a NanoDrop $^{\mathrm{TM}} 1000$ (Thermo Fisher Scientific, Wilmington, USA) and adjusted to a final concentration of $100 \mathrm{ng} \cdot \mu \mathrm{L}^{-1}$ with RNase-free water (Qiagen, Mississauga, ON, Canada).

\subsection{Fluorescent RAP-PCR}

Primer design is described in the Supplementary Material, Sections 1 and 2. RNA was used at a concentration of $15 \mathrm{ng} \cdot \mu \mathrm{L}^{-1}$ with 19 units of SUPERase-In and $2.5 \mu \mathrm{mol} \cdot \mathrm{L}^{-1}$ of an equal ratio of primers ST1-ST13 (Supplementary Material, Tab. SI). The mixture was incubated at $65{ }^{\circ} \mathrm{C}$ for $5 \mathrm{~min}$ then immediately placed on ice for $1 \mathrm{~min}$. The final volume of the retrotranscription reaction was $19 \mu \mathrm{L}$ and contained: $2 \mathrm{mmol} \cdot \mathrm{L}^{-1}$ of total dNTPs, 190 units of SuperScript ${ }^{\mathrm{TM}}$ III (Invitrogen, Burlington, ON, Canada), $3.7 \mu \mathrm{L}$ of $5 \mathrm{X}$ buffer and $5 \mathrm{mmol} \cdot \mathrm{L}^{-1}$ of DTT (dithiothreitol). The reverse transcription reactions were incubated at $25{ }^{\circ} \mathrm{C}$ for $10 \mathrm{~min}$. The polymerization step was carried out at $45^{\circ} \mathrm{C}$ for $2 \mathrm{~h}$, and a final reverse transcriptase inactivation step was applied at $70{ }^{\circ} \mathrm{C}$ for $15 \mathrm{~min}$.

A quantity of $20 \mathrm{ng}$ of cDNA was used as template for PCR amplification. For $20 \mu \mathrm{L}$ of final volume, each reaction mixture contained: $1.67 \mathrm{mmol} \cdot \mathrm{L}^{-1}$ of $\mathrm{MgSO}_{4}$, $700 \mu \mathrm{mol} \cdot \mathrm{L}^{-1}$ of total dNTPs, 1.34 units of Hot Start Kod polymerase (EMD Biosciences, Inc., Novagen ${ }^{\circledR}$, Madison, WI, USA), $2 \mu \mathrm{mol} \cdot \mathrm{L}^{-1}$ of one nonlabeled primer and $2 \mu \mathrm{mol} \cdot \mathrm{L}^{-1}$ of one fluorescent primer. The first step was $95^{\circ} \mathrm{C}$ for 10 min for RNA degradation and Hot Start polymerase activation. The second step was a low stringency annealing at $35^{\circ} \mathrm{C}$ for $40 \mathrm{~min}$, enabling saturation of all the potential hybridizing sites [30]. The third step was a final elongation of the second strand cDNA at $72^{\circ} \mathrm{C}$ for $5 \mathrm{~min}$. Then the following 30 PCR cycles were performed with high stringency cycling: $95{ }^{\circ} \mathrm{C}, 30 \mathrm{~s}$; $55^{\circ} \mathrm{C}, 40 \mathrm{~s}$; and $72{ }^{\circ} \mathrm{C}, 60 \mathrm{~s}$. The PCR amplification was mixed with $500 \mu \mathrm{L}$ of TE $\left(10 \mathrm{mmol} \cdot \mathrm{L}^{-1}\right.$ Tris and $1 \mathrm{mmol} \cdot \mathrm{L}^{-1}$ EDTA, pH 8) and loaded on a Microcon ${ }^{\circledR}$ YM100 (Millipore, Billerica, MA, USA). The amplicons were washed four times with successive passages of $500 \mu \mathrm{L}$ of TE on the same column. Elution was carried out with $50 \mu \mathrm{L}$ of TE, and PCR products were quantified by spectrophotometry at $260 \mathrm{~nm}$.

\subsection{Separation by polyacrylamide gel electrophoresis}

PCR amplifications (3 $\mu \mathrm{g})$ were separated on $6 \%$ polyacrylamide gels (acrylamide:bisacrylamide with a 29:1 ratio). Electrophoresis was run at $100 \mathrm{~V}$ for $24 \mathrm{~h}$ at $4{ }^{\circ} \mathrm{C}$. Ethidium bromide was used for staining DNA, which was visualized by UV transillumination.

\subsection{Amplicon separation by capillary electrophoresis}

A quantity of $75 \mathrm{ng}$ of purified amplicons was mixed with $10 \mu \mathrm{L}$ of formamide and $0.3 \mu \mathrm{L}$ of MapMarker ${ }^{\circledR} 1000$ (Bio-Ventures, Murfreesboro, TN, USA). The mixture was heated at $99{ }^{\circ} \mathrm{C}$ for $5 \mathrm{~min}$ then cooled on ice for $1 \mathrm{~min}$ and injected (injection voltage: $1 \mathrm{kV}$, injection duration: $30 \mathrm{~s}$ ) in the ABI Prism ${ }^{\circledR} 3100$ Genetic Analyzer (Applied Biosystems, Foster City, USA).

Separation was performed using capillaries filled with POP6 polymer under these parameters: run voltage: $15 \mathrm{kV}$, total 
data points for each run: 24178 . The electropherograms were acquired with the GeneMapper ${ }^{\circledR}$ version 3.7 software (Applied Biosystems) under these advanced microsatellite parameters: no smoothing; baseline $=51$; peak threshold (blue) $=1$; minimum peak half width $=0$; polynomial degree search $=5$; and window size $=15$. To standardize MapMarker ${ }^{B}$ sizing, flag quality was set at low-quality range from 0 to $1 \mathrm{E}-6$ then pass-range from $1 \mathrm{E}-5$ to 1. Panel manager marker sizing and microsatellite analysis was applied from 50 to 1500 bases. An AFLP analysis was performed and for each replicate, the size (in bases) and the height (in fluorescent units) of peaks were exported to Excel.

\subsection{Statistical analysis}

To prevent statistical problems resulting from peak absence of some very small peaks (no height reported), the minimum height of the peaks detected in the run (usually from 1 to 10 under a 6000 scale graduation) was substituted for each of the peaks not detected with GeneMapper (around 1\% of the peaks were not detected by the software). Height data were transformed by Neperian logarithm to linearize peak distribution then standardized with AMIADA [33] using the sum of all the heights. Standardization was carried out to a null average and a unitary standard deviation, allowing comparisons among replicates. For each sample withdrawn at one time point, the resulting eight electropherograms were concatenated under Excel ${ }^{\circledR}$ (for milk thermal treatments, the electropherograms from each time point were also concatenated).

Hierarchical clustering (HC) and principal component analysis (PCA) were carried out using " $\mathrm{R}$ " statistical software. Euclidean distance was used as the metric because it is a direct similarity measure, allowing rapid and intuitive interpretation of information produced (equation (1)). HC used average linkage and was computed with a bootstrap of 10000 permutations. PCA and statistical significance (using ANOVA and Tukey honest significant differences) were computed with the "R" package. The number of differentially expressed peaks was identified using the SAM algorithm (FDR $=0.4$, 10000 permutations) from the MEV 4 software [24] and divided by the total number of peaks:

$$
\begin{aligned}
& \text { Similarity }_{A / B}=\frac{1}{1+\text { Distance }_{A \rightarrow B}} \\
& \text { Distance }_{A \rightarrow B}=\sqrt{2\left(1-\text { Similarity }_{A / B}\right) .}
\end{aligned}
$$

\section{RESULTS AND DISCUSSION}

The mixed starter culture responded to the state of milk nutrient accessibility by adapting their global RNA profiles. The bacterial transcriptome is composed mainly of rRNA and tRNA, while the fraction of mRNA is low (around 5\%). Fragments generated by FRAP-PCR can thus be attributed to all RNA transcripts. While many different individual mRNA molecules are represented in the transcriptome (high complexity), the multiple copies of rRNA and tRNA are of similar sequence (low complexity), and thus the same rRNA amplicons will migrate to the same distance. This will reduce its effect on the overall profile composed of 1000 peaks, as long as primers and reaction components are present in sufficient quantity to avoid depletion.

\subsection{Effect of milk type and treatment on defined mixed starter transcription profiles by FRAP-PCR}

In order to determine the reproducibility of the method and to select reference conditions, different milk types and thermal treatments were first compared. The technique showed high reproducibility, as each peak 
of electropherograms was present in triplicate experiments (Supplementary Material, Fig. S2) and replicates were grouped by HC (Supplementary Material, Fig. S3) as well as by PCA (Supplementary Material, Fig. S4). Cluster separation could be attributed to milk type used during the fermentation even if $\mathrm{pH}$ could not differentiate most of the milk types (Tab. I). Clusters of electropherograms coming from cultures in microfiltered, pasteurized and UHT milk were located near to one another and separated from the profiles obtained with autoclaved SMP. The first two components of PCA (Supplementary Material, Fig. S3) explain $>50 \%$ of the total variance. The first component, explaining nearly $40 \%$ of the variance, separated autoclaved from nonautoclaved SMP, whereas the second component divided SMP autoclaved for 10 or $15 \mathrm{~min}$.

Pasteurization and microfiltration are not damaging for milk constituents as there are few physicochemical changes compared to raw milk $[20,25]$, but milk contains various active RNases [16] and could have microbial contaminants [18]. The RNases could alter starter RNA during extraction and the microbial contaminants could be cocultivated with starter (especially during the two subcultures) and these will give irreproducible RNA profiles. The autoclaving of milk inactivates RNases and kills all microbial contaminants, but the results of this study show that autoclaved SMP induced significant transcriptome changes in the starter compared to microfiltered milk. The autoclaved SMP is not recommended for starter activity study for two reasons: (i) the starter RNA profile of autoclaved SMP was very different from the same SMP treated by pasteurization; (ii) with only $5 \mathrm{~min}$ difference between them, the two autoclaving times induced significant starter RNA modifications, indicating a potential deviation of starter activity if the autoclaving of milk is not perfectly time controlled (e.g. cooling time).
Starter fermenting UHT or pasteurized SMP has nearly the same RNA profile as in microfiltered milk, so these two milk types did not notably influence gene transcription. SMP has well-known solubilization problems and so could lead to modification of water activity between different experiments. UHT milk was the most suitable milk for starter gene transcription study, as there was no need of solubilization, no RNA or bacterial contaminants [3], and milk RNases are inactivated by the high temperature reached (around $140{ }^{\circ} \mathrm{C}$ ) [16]. The UHT treatment did not influence the starter transcriptome as much as autoclaved SMP, so this high temperature treated milk could be used for preparing starter cultures for RNA study of cheese fermentation without important risk of contamination.

\subsection{Effect of $\mathrm{CO}_{2}$ acidification and neutralization on transcription profiles of defined mixed starter cultivated in whole milk}

Oxygen displacement by carbon dioxide prevents the growth of aerobic bacteria, but anaerobic bacteria can also be affected by $\mathrm{CO}_{2}$ [22]. Milk carbon dioxide dissolution leads to a rapid drop of $\mathrm{pH}$ caused by carbonic acid formation in milk aqueous phase, but this important acid production is not the only cause of bacterial growth inhibition [9]. Carbon dioxide has important effects on bacterial membrane permeability [7] but more complex effects have been studied, such as interference with bacterial metabolism leading to changes in carbohydrate utilization [17], lowering intracellular $\mathrm{pH}$ [7] and varying enzyme activities [6] (such as extracellular lipase [23]). All these combined effects induce a stress that decreases bacterial multiplication and acidification rate.

Samples were taken at the T4 time point, and the pasteurized whole milk cluster was used as control to discover the influence 


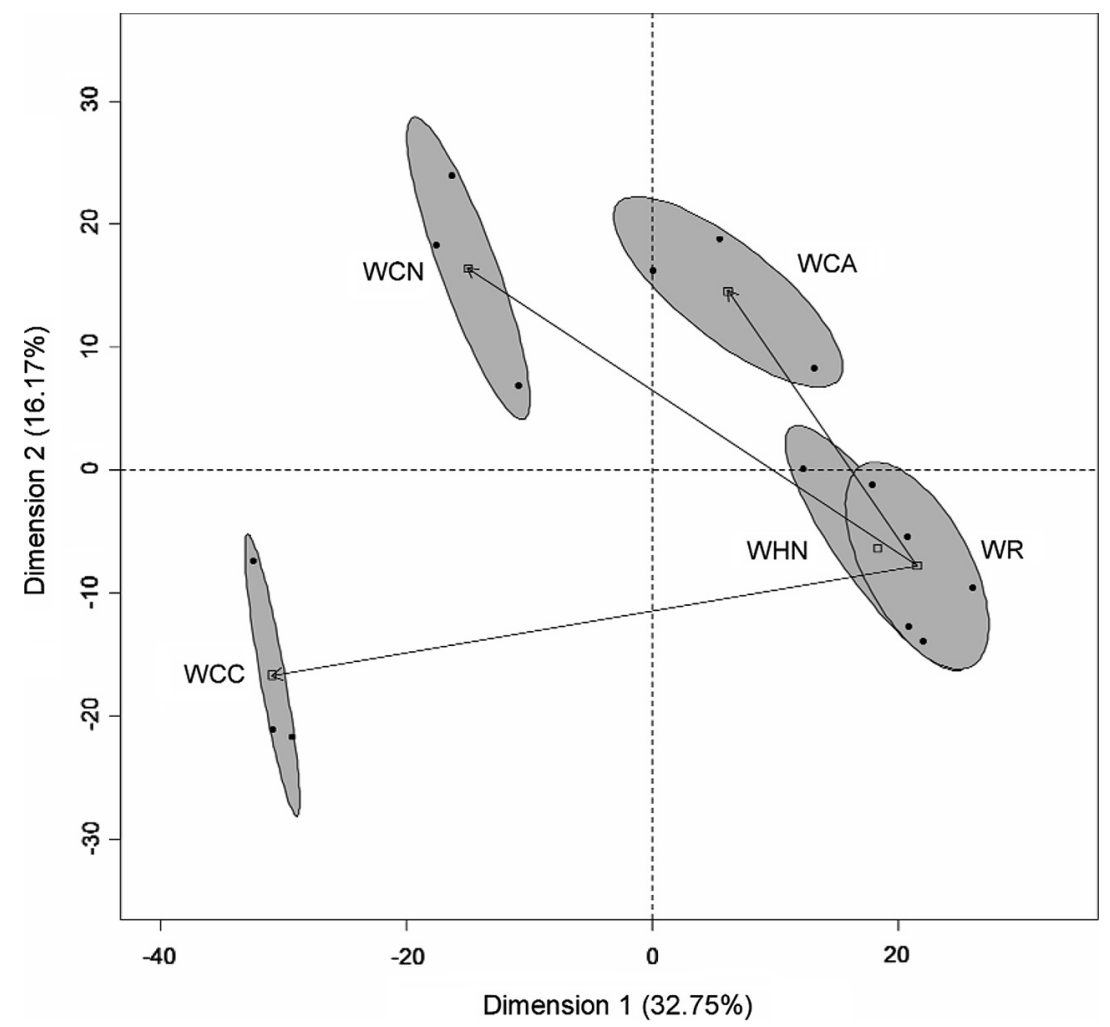

Figure 1. PCA of fluorescent RAP-PCR amplicon profiles obtained from RNA extracted from defined mixed culture fermentation of pasteurized whole milk pretreated with different acidification and neutralization procedures. WR is the pasteurized whole milk reference profile; $\mathrm{WCN}$ is whole milk acidified with $\mathrm{CO}_{2}$ and neutralized with $\mathrm{NaOH}$; WCC is whole milk acidified with $\mathrm{CO}_{2}$ then neutralized with $\mathrm{Na}_{2} \mathrm{CO}_{3}$; WCA is whole milk acidified with $\mathrm{CO}_{2}$ and neutralized by agitation; and WHN is whole milk acidified with $\mathrm{HCl}$ and neutralized with $\mathrm{NaOH}$. Gray shading represents the clustering of the three experimental repetitions $(\bullet)$ inside an ellipse which represents a confidence level of $95 \%$. (口) Cluster's barycenter.

of the acidification and neutralization procedures (Tab. II) on RNA profiles. The $\mathrm{pH}$ was significantly higher at $\mathrm{T} 4$ in $\mathrm{CO}_{2}$-acidified milk that was neutralized by $\mathrm{NaOH}$ or $\mathrm{Na}_{2} \mathrm{CO}_{3}$ than after the other treatments of pasteurized whole milk. The first two components of PCA totalized around $50 \%$ of the variance (Fig. 1). The first component (32.75\% of the variance) separates $\mathrm{CO}_{2-}$ acidified milk from pasteurized milk and $\mathrm{HCl}$-acidified milk. The second component explained $16.17 \%$ of the variance and could also be associated with $\mathrm{CO}_{2}$ treatment, as the $\mathrm{CO}_{2}$ profiles are further from the central axis than those of pasteurized and $\mathrm{HCl}$-acidified milk.

Compared to pasteurized whole milk, the RNA profile of starter fermenting $\mathrm{CO}_{2}$-acidified whole milk which was neutralized by $\mathrm{NaOH}$ or $\mathrm{Na}_{2} \mathrm{CO}_{3}$ showed important modifications. The RNA profile of starter fermenting $\mathrm{HCl}$-acidified whole milk coupled with $\mathrm{NaOH}$ for the neutralization did not show any statistical difference from 
whole milk, suggesting that it was not the acidification and $\mathrm{NaOH}$ neutralization steps that were causing RNA profile modifications. Therefore, milk acidification by $\mathrm{CO}_{2}$ could modify RNA profiles of the mixed culture. The type of neutralization step also influenced gene transcription. The cluster of electropherograms from starter cultivated on $\mathrm{CO}_{2}$-acidified and $\mathrm{Na}_{2} \mathrm{CO}_{3}$-neutralized whole milk was the farthest removed from the whole milk profile, indicating more extensive modification of the starter RNA profile. Furthermore, this type of neutralization led to important $\mathrm{pH}$ buffer action, which could introduce significant delays in acidification needed for cheese manufacturing. Carbon dioxide dissipation by agitation seems a good technique for neutralization to regain similar reference starter activity because this treatment led to only small starter RNA changes.

\subsection{Effect of $\mathrm{CO}_{2}$ acidification and neutralization on transcription profiles of defined mixed starter cultivated in skim milk}

Pasteurized skim milk without $\mathrm{CO}_{2}$ treatment or neutralization was used as the fermentation reference. Two different treatments were applied to pasteurized skim milk: acidification with $\mathrm{CO}_{2}$ to $\mathrm{pH} 6.2$ without neutralization and acidification with $\mathrm{CO}_{2}$ to $\mathrm{pH} 6.2$ followed by neutralization by agitation at $4{ }^{\circ} \mathrm{C}$. Experiments using pasteurized whole milk were repeated for a reference profile among the various replicates. The PCA results (Fig. 2) show that FRAPPCR profiles from mixed cultures in skim milk with different carbonation or agitation treatments were separated from those of pasteurized whole milk along the first component. The PCA shows clustering of all skim milk samples into one group, whereas treated whole milks were well separated from one another. All the FRAP-PCR profiles from skim milk were electrophoresed on a $6 \%$ acrylamide gel (Supplementary
Material, Fig. S5). For each primer pair, no differences between the band profiles could be detected. Thus, $\mathrm{CO}_{2}$ acidification experiments using pasteurized skim milk did not induce detectable modifications in electropherograms obtained either by FRAP-PCR or by polyacrylamide gel electrophoresis. Protein and mineral contents are essentially the same between whole milk and skim milk [21], leading to the conclusion that there was no irreversible action of $\mathrm{CO}_{2}$ on casein or colloidal calcium phosphate that could influence starter gene transcription during fermentation. Therefore, the fat globules could be the origin of the difference between pasteurized whole milk and skim milk in the effect of $\mathrm{CO}_{2}$ acidification on starter RNA profiles. Carbon dioxide treatment could lead to imprisonment of carbonated molecules in milk fat globules [28], which could be released during cheese manufacture, leading to interactions with starter bacteria even if the L. lactis subsp. cremoris strains used were resistant to $\mathrm{CO}_{2}$ influence [5].

\subsection{Rennet and $\mathrm{NaCl}$ influence on defined mixed starter transcriptome profiles}

At the salt concentrations used in this study, the three individual strains have about the same growth (data not shown). Mixed starter fermented with different $\mathrm{NaCl}$ and rennet concentrations did not show any influence on the final $\mathrm{pH}$ attained in the Pearce test (Tab. III). Differentially expressed peaks (either activated or repressed compared to the standard condition) were identified by SAM analysis (Tab. IV). The high rennet treatment resulted in the same proportion of activated peaks (i.e. peaks of greater height than in the standard condition) as for repressed peaks, while the low rennet condition showed double the number of repressed peaks compared to activated ones (Tab. IV). High $\mathrm{NaCl}$ concentration resulted in almost the same number 


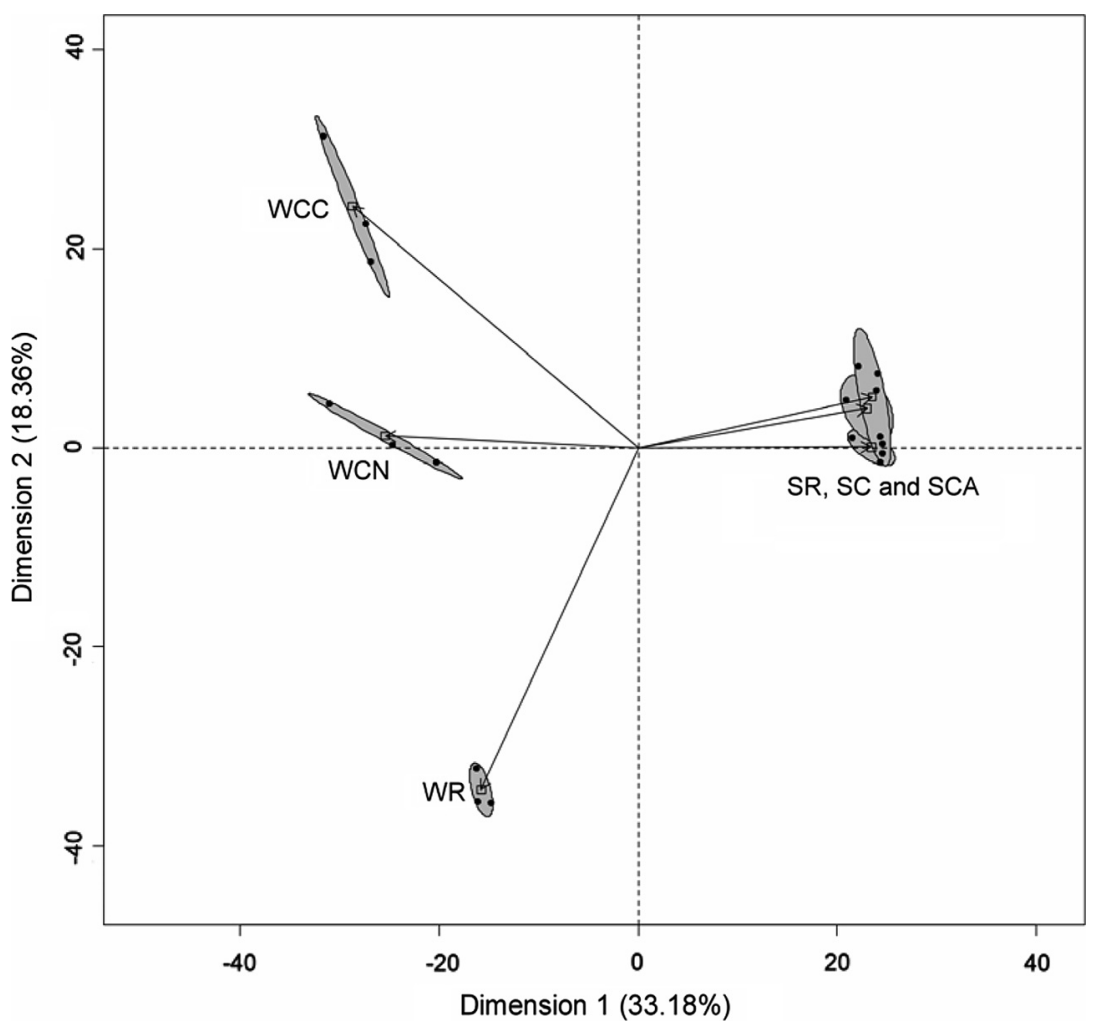

Figure 2. PCA of fluorescent RAP-PCR profiles obtained from RNA extracted from defined mixed culture fermentation of pasteurized whole or skim milk treated by acidification and neutralization. WR is the whole milk reference profile; WCN is whole milk acidified with $\mathrm{CO}_{2}$ and neutralized with $\mathrm{NaOH}$; WCC is whole milk acidified with $\mathrm{CO}_{2}$ then neutralized with $\mathrm{Na}_{2} \mathrm{CO}_{3}$; SR is pasteurized skim milk reference with no treatment; $\mathrm{SC}$ is pasteurized skim milk treated with $\mathrm{CO}_{2}$; and SCA is pasteurized skim milk treated with $\mathrm{CO}_{2}$ then neutralized by agitation. Gray shading represents the clustering of the three experimental repetitions $(\bullet)$ inside an ellipse which represents a confidence level of $95 \%$. ( $\square$ ) Cluster's barycenter.

Table III. $\mathrm{pH}$ of UHT milk at T5 ( $1 \mathrm{~h}$ and 45 min after the T4 time point) of the modified Pearce starter activity test.

\begin{tabular}{lccc}
\hline Condition & $\mathrm{NaCl}\left(\mathrm{g} \cdot \mathrm{L}^{-1}\right)$ & Rennet $\left(\mathrm{g} \cdot \mathrm{L}^{-1}\right)$ & $\mathrm{pH} \pm \mathrm{SD}^{*}$ \\
\hline Standard condition & 22.5 & 0.08 & $5.10 \pm 0.06$ \\
High rennet & 22.5 & 0.12 & $5.14 \pm 0.05$ \\
Low rennet & 22.5 & 0.04 & $5.00 \pm 0.06$ \\
High $\mathrm{NaCl}$ & 25 & 0.08 & $5.11 \pm 0.05$ \\
Low $\mathrm{NaCl}$ & 15 & 0.08 & $5.06 \pm 0.06$ \\
\hline
\end{tabular}

${ }^{*} \mathrm{SD}$ is standard deviation. 
Table IV. Number of peaks differentially expressed for each condition compared to standard conditions identified using the SAM algorithm (FDR $=0.4 \%, 10000$ permutations) of the MEV 4.0 software. Percentage of the total is reported in parentheses.

\begin{tabular}{lcc}
\hline Condition & Activated peaks & Repressed peaks \\
\hline High rennet & $22(2 \%)$ & $17(2 \%)$ \\
Low rennet & $18(2 \%)$ & $50(4 \%)$ \\
High $\mathrm{NaCl}$ & $42(4 \%)$ & $28(2 \%)$ \\
Low $\mathrm{NaCl}$ & $8(1 \%)$ & $50(4 \%)$ \\
\hline
\end{tabular}

of activated peaks as the number of repressed peaks identified when low $\mathrm{NaCl}$ concentration was used.

The PCA clusters are separated by the two components simultaneously, indicating that each of the two first eigenvectors was a combination of $\mathrm{NaCl}$ and rennet influence (Fig. 3). These eigenvectors were nearly equal in the variance explained $(24.14 \%$ for the first and $16.25 \%$ for the second). The profiles obtained from the RNA extracted from mixed cultures with low rennet concentration were the farthest from the standard cluster near the center and showed the highest positive vector in the first dimension. Comparison with the reference cluster shows that both the salt and rennet vectors (high and low) are nearly opposite in direction, and are in opposing quadrants, indicating opposing correlation of the variance caused by condition-specific peaks. The cluster corresponding to the standard $\mathrm{NaCl}$ concentration was equally centered between the two profile clusters representing low and high $\mathrm{NaCl}$ concentrations, even if the concentration gradient varied $\left(7.5 \mathrm{~g} \cdot \mathrm{L}^{-1}\right.$ between low and standard compared to only $2.5 \mathrm{~g} \cdot \mathrm{L}^{-1}$ between standard and high concentration). This indicates an important influence on the transcriptome caused by $\mathrm{NaCl}$ addition and less difference when $\mathrm{NaCl}$ decreased. As the vector of the clusters is equally distanced from both principal components, this indicates a combination of the influence of both $\mathrm{NaCl}$ and rennet. Rennet concentration thus had an opposite effect from $\mathrm{NaCl}$, as the cluster of profiles from the lowest rennet concentration was at a greater distance from the profile obtained with the standard concentration of rennet. This indicates that gene transcription of the starter was greatly modified by low rennet condition and less by high rennet addition.

\section{CONCLUSION}

RNA profiles of starter fermenting $\mathrm{CO}_{2}-$ acidified milk were modified by $\mathrm{CO}_{2}$ molecules presumably dissolved in fat globules and slowly released. Agitation was more effective than $\mathrm{NaOH}$ or $\mathrm{Na}_{2} \mathrm{CO}_{3}$ for neutralization to return the profile to that obtained in whole milk. FRAP-PCR was able to show that starter gene transcription was more influenced by an increase in $\mathrm{NaCl}$ compared to a decrease in $\mathrm{NaCl}$. Rennet at a high concentration had only a little influence on gene transcription, but low rennet activity had great influence. This indicates that an increase in $\mathrm{NaCl}$ must be compensated by an increase in rennet. For this starter, rennet activity appeared to be optimal at standard concentration.

This is the first report of the application of FRAP-PCR to the study of starter activity in cultures emulating cheese fermentation. This method could be used to determine the level of influence of parameters and help to understand the way changes in Cheddar cheese fermentation procedures could interfere with global gene transcription of the starter. By determining starter gene responses during Cheddar cheese manufacturing, optimal 


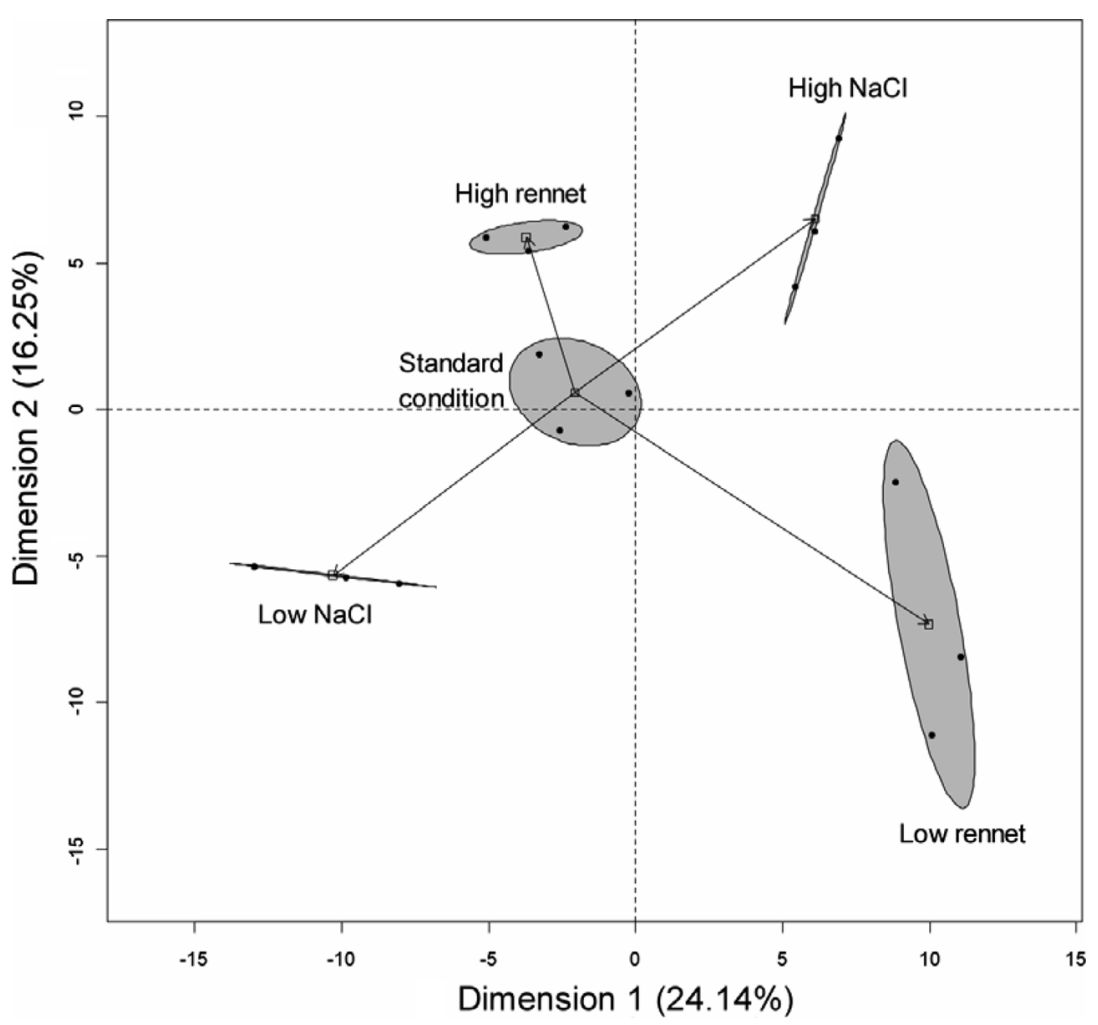

Figure 3. PCA of fluorescent RAP-PCR profiles obtained from RNA extracted from fermentation with low, standard and high concentrations of rennet and $\mathrm{NaCl}$ (as listed in Sect. 2). Gray shading represents the clustering of the three experimental repetitions $(\bullet)$ inside an ellipse which represents a confidence level of $95 \%$. ( $\square$ ) Cluster's barycenter.

cheese fermentation could be predicted by comparison with a reference such as a cheese with an excellent grade. Another potential of FRAP-PCR could be the detection of differentially expressed peaks due to starter expressing phage RNA, thus revealing potential fermentation failure due to phage. This technique could also be used for studying bacterial associations in order to further our understanding of microbial interactions in food matrices.

Acknowledgments: The authors gratefully acknowledge the financial support provided by the Fonds Québécois de recherche sur la nature et les technologies (FQRNT), Novalait, Inc., the Ministère de l'Agriculture, des Pêcheries et de l'Alimentation du Québec (MAPAQ) as well as Agriculture and Agri-Food Canada.

\section{REFERENCES}

[1] Bachem C.W., van der Hoeven R.S., de Bruijn S.M., Vreugdenhil D., Zabeau M., Visser R.G., Visualization of differential gene expression using a novel method of RNA fingerprinting based on AFLP: analysis of gene expression during potato tuber development, Plant J. 9 (1996) 745-753.

[2] Bauer D., Muller H., Reich J., Riedel H., Ahrenkiel V., Warthoe P., Strauss M., Identification of differentially expressed 
mRNA species by an improved display technique (DDRT-PCR), Nucleic Acids Res. 21 (1993) 4272-4280.

[3] Birlouez-Aragon I., Sabat P., Gouti N., A new method for discriminating milk heat treatment, Int. Dairy J. 12 (2002) 52-57.

[4] Crump D., Chiu S., Trudeau V.L., Kennedy S.W., Fluorescent RNA arbitrarily primed polymerase chain reaction. A new differential display approach to detect contaminantinduced alterations of gene expression in wildlife species, in: Cristofre Martin C. (Ed.), Methods in Molecular Biology: Environmental Genomics, Vol. 410, Humana Press Inc., Totowa, USA, 2008, pp. 15-27.

[5] Enfors S.O., Molin G., Effect of high concentrations of carbon dioxide on growth rate of Pseudomonas fragi, Bacillus cereus and Streptococcus cremoris, J. Appl. Bacteriol. 48 (1980) 409-416.

[6] Gill C.O., Tan K.H., Effect of carbon dioxide on growth of Pseudomonas fluorescens, Appl. Environ. Microbiol. 38 (1979) 237-240.

[7] Hon S.I., Pyun Y.R., Membrane damage and enzyme inactivation of Lactobacillus plantarum by high pressure $\mathrm{CO}_{2}$ treatment, Int. J. Food Microbiol. 63 (2001) 19-28.

[8] Jones S.W., Cai D., Weislow O.S., EsmaeliAzad B., Generation of multiple mRNA fingerprints using fluorescence-based differential display and an automated DNA sequencer, Biotechniques 22 (1997) 536543.

[9] King J.S., Mabbitt L.A., Preservation of raw milk by addition of carbon dioxide, J. Dairy Res. 49 (1982) 439-447.

[10] Liang P., Pardee A.B., Differential display of eukaryotic messenger RNA by means of the polymerase chain reaction, Science 257 (1992) 967-971.

[11] Luehrsen K.R., Marr L.L., van der Knaap E., Cumberledge S., Analysis of differential display RT-PCR products using fluorescent primers and GENESCAN software, Biotechniques 22 (1997) 168-174.

[12] Ma Y., Barbano D.M., Effect of temperature of $\mathrm{CO}_{2}$ injection on the $\mathrm{pH}$ and freezing point of milks and creams, J. Dairy Sci. 86 (2003) 1578-1589.

[13] Makarova K., Slesarev A., Wolf Y., Sorokin A., Mirkin B., Koonin E., Pavlov A., Pavlova N., Karamychev V., Polouchine N., Shakhova V., Grigoriev I., Lou Y., Rohksar D., Lucas S., Huang K.,
Goodstein D.M., Hawkins T., Plengvidhya V., Welker D., Hughes J., Goh Y., Benson A., Baldwin K., Lee J.H., Diaz-Muniz I., Dosti B., Smeianov V., Wechter W., Barabote R., Lorca G., Altermann E., Barrangou R., Ganesan B., Xie Y., Rawsthorne H., Tamir D., Parker C., Breidt F., Broadbent J., Hutkins R., O'Sullivan D., Steele J., Unlu G., Saier M., Klaenhammer T., Richardson P., Kozyavkin S., Weimer B., Mills D., Comparative genomics of the lactic acid bacteria, Proc. Natl. Acad. Sci. USA 103 (2006) 15611-15616.

[14] Martin J.D., Werner B.G., Hotchkiss J.H., Effects of carbon dioxide on bacterial growth parameters in milk as measured by conductivity, J. Dairy Sci. 86 (2003) 19321940.

[15] Meade J.D., Cho Y.J., Fisher J.S., Walden J.C., Guo Z., Liang P., Automation of fluorescent differential display with digital readout, in: Liang P., Meade J.D., Pardee A.B. (Eds.), Methods in Molecular Biology: Differential Display Methods and Protocols, Vol. 317, Humana Press Inc., Totowa, USA, 2006, pp. 23-57

[16] Meyer D.H., Kunin A.S., Maddalena J., Meyer W.L., Ribonuclease activity and isoenzymes in raw and processed cows' milk and infant formulas, J. Dairy Res. 70 (1987) 1797-1803.

[17] Molin G., Effect of carbon dioxide on growth of Pseudomonas putida ATCC 11172 on asparagine, citrate, glucose, and lactate in batch and continuous culture, Can. J. Microbiol. 31 (1985) 763-766.

[18] Nielsen E.W., Principles of cheese production, in: Hui Y., Meunier-Goddik L., Hansen A., Josephsen J., Nip W.-K., Stanfield P., Toldrá F. (Eds.), Handbook of Food and Beverage Fermentation Technology, Marcel Dekker, New York, USA, 2004, pp. 219-239.

[19] Pearce L.E., Activity tests for cheese starter cultures, New Zealand, J. Dairy Technol. 4 (1969) 246-247.

[20] Pedersen P.J., Microfiltration for the reduction of bacteria in milk and brine, new applications of membrane processes, Int. Dairy Fed. Special Issue No. 9201 (1992) 33-50.

[21] Posati L.P., Orr M.L., Composition of foods: dairy and egg products; raw, processed, prepared, Agriculture Handbook No. 8-1, Agricultural Research Service, USDA, Washington, USA, 1976. 
[22] Roberts R.F., Torrey G.S., Inhibition of psychrotrophic bacterial growth in refrigerated milk by addition of carbon dioxide, J. Dairy Sci. 71 (1988) 52-60.

[23] Rowe M.T., Effect of carbon dioxide on growth and extracellular enzyme production by Pseudomonas fluorescens B52, Int. J. Food Microbiol. 6 (1988) 51-56.

[24] Saeed A.I., Sharov V., White J., Li J., Liang W., Bhagabati N., Braisted J., Klapa M., Currier T., Thiagarajan M., Sturn A., Snuffin M., Rezantsev A., Popov D., Ryltsov A., Kostukovich E., Borisovsky I., Liu Z., Vinsavich A., Trush V., Quackenbush J., TM4: a free open-source system for microarray data management and analysis, Biotechniques 34 (2003) 374-378.

[25] Scaloni A., Perillo V., Franco P., Fedele E., Froio R., Ferrara L., Bergamo P., Characterization of heat-induced lactosylation products in caseins by immunoenzymatic and mass spectrometric methodologies, Biochim. Biophys. Acta 1598 (2002) 30-39.

[26] Schena M., Shalon D., Davis R.W., Brown P.O., Quantitative monitoring of gene expression patterns with a complementary DNA microarray, Science 270 (1995) 467-470.
[27] Sturtevant J., Applications of differentialdisplay reverse transcription-PCR to molecular pathogenesis and medical mycology, Clin. Microbiol. Rev. 13 (2000) 408-427.

[28] Walstra P., Wouters J.T.M., Geurts T.J., Dairy Science and Technology, CRC Press, Boca Raton, USA, 2006.

[29] Welsh J., Chada K., Dalal S.S., Cheng R., Ralph D., McClelland M., Arbitrarily primed PCR fingerprinting of RNA, Nucleic Acids Res. 20 (1992) 4965-4970.

[30] Welsh J., McClelland M., Fingerprinting genomes using PCR with arbitrary primers, Nucleic Acids Res. 18 (1990) 7213-7218.

[31] Williams J.G., Kubelik A.R., Livak K.J., Rafalski J.A., Tingey S.V., DNA polymorphisms amplified by arbitrary primers are useful as genetic markers, Nucleic Acids Res. 18 (1990) 6531-6535.

[32] Wong K.K., McClelland M., Stress-inducible gene of Salmonella typhimurium identified by arbitrarily primed PCR of RNA, Proc. Natl. Acad. Sci. USA 91 (1994) 639-643.

[33] Xia X., Xie Z., AMADA: analysis of microarray data, Bioinformatics 17 (2001) 569-570. 